\title{
In vitro Evaluation of Fungicides against Bipolaris sorokiniana Causing Spot Blotch of Barley (Hordeum vulgare L.)
}

\author{
Kavita $^{1^{*}}$, S.K. Pande ${ }^{1}$, Jay Kumar Yadav ${ }^{1}$ and Dalbeer ${ }^{2}$ \\ ${ }^{1}$ Department of Plant Pathology, ${ }^{2}$ Department of Genetic and Plant Breeding, N. D. University of \\ Agriculture and Technology, Faizabad-224229, India \\ *Corresponding author
}

A B S T R A C T

\begin{tabular}{|l|}
\hline Key w or d s \\
Barley, Bipolaris \\
sorokiniana, \\
Different \\
Fungicides
\end{tabular}

An experiment conducted in Plant Pathology Laboratory Narendra Deva University of Agriculture and Technology, Narendra Nagar, Kumarganj, Faizabad (U.P.) during 2015 Efficacy of 15 fungicides ware evaluated at $0.05 \%, 0.5 \%, 0.1 \%$ and $2 \%$ for studying their inhibitory effect on the mycelia growth of Bipolaris sorokiniana by using food poison technique. In present study the data was recorded, the maximum mycelial growth inhibition was recorded in inoculation after 7 days Propiconazole $(0.1 \%) 87.77 \%$, and Propiconazole $(0.05 \%) 81.57 \%$ and radial mycelial growth $11.00 \mathrm{~mm}$ and $16.57 \mathrm{~mm}$ followed by Hexaconazole $(0.2 \%)$ and Hexaconazole $(0.1 \%) 77.98 \%$ and $70.37 \%$ mycelial growth inhibition and radial mycelial growth $19.81 \mathrm{~mm}$ and $26.65 \mathrm{~mm}$. The lowest mycelial growth inhibition was recorded $\mathrm{T}_{1}$ Achook $0.5 \%$ and $\mathrm{T}_{2}$ Achook $0.2 \% 7.75 \%$ and $0.78 \%$ and radial mycelia growth $83.01 \mathrm{~mm}$ and $89.56 \mathrm{~mm}$. The results revealed that inhibition percentages were increase with the increased in concentration of all fungicides used in this study.

\section{Introduction}

Barley (Hordeum vulgare L. 2n=14, sub family Poaceae) a crop of winter season is grown eco-friendly worldwide for food, feed and forage under various agro climatic situation. During 2015-16 India had about 6.55 lakh ha area with production of 16.18 lakh metric tonnes and productivity of 24.70 q/ha. In U.P Barley occupied an area of 1.46 lakh ha with a total production of 3.58 lakh metric ton with productivity of $24.50 \mathrm{q} / \mathrm{ha}$. Uttar Pradesh alone contributes more than one third of India's total production of Barley (Anonymous, 2016).

Plant diseases, especially foliar diseases, are one of the factors that contribute most to limit the Barley production in India. Barley is greatly affected by many fungal diseases, accounting considerable yield loss every year. The global yield losses of Barley caused by foliar diseases are estimated to range from $10 \%$ to $40 \%$, amounting to billions of dollars per season (Sharma and Duveiller, 2006).

However, the disease varies from country to country and the Spot blotch disease caused by the fungus Bipolaris sorokiniana (teleomorph Cochliobolus sativus) is one of the most important fungal disease of Barley found worldwide but is most serious in tropical areas where Barley and wheat are grown many factors, including climate conditions 
(rainfall, temperature and humidity) and agricultural practices, influence the development and spread of Bipolaris sorokiniana causing several diseases in its host worldwide and produces a broad range of symptoms such as foot and root rot, leaf blotch and black point of seeds and infected seeds can be the main source of inoculums, especially in newly cultivated areas. The survival of free inactive conidia in soil for more than one year and repeated cultivation of the same crop provides another source of infection and alternative hosts such as grasses can also be a source of the infection (Pandey et al., 2005).

Spot blotch (Bipolaris sorokiniana (Sacc. Ex.Sorok) Shoem formely Helminthosporium sativum, Syn. Drechslera sorokiniana teleomorph Cochliobolus sativus (Ito adn Kuribisi) is an important disease of Barley and wheat, commonly occuring in wheat-rice cropping sequence areas of country.

The disease affected all plant parts and can cause up to $100 \%$ damage to the crop. Fungicide can be an effective agent to control this disease. They are chemical compound that controls fungal disease by specifically inhibiting or killing the fungus causing the disease

Fungicides that have curative properties reduce disease severity and increase the productivity of crop. Cultural practices often do not provide adequate disease control and resistant cultivars are not available or not acceptable in mark, certain high value crops have an extremely low tolerance for disease symptoms.

In those case using fungicide is the most suitable to fight against diseases. It effectively controls the sudden attack of any disease so epidemic can be avoided easily (McGrath, 2004). The isolates of $B$. sorokiniana collected from various cities of Bangladesh were examined for their sensitivity. The conventional breeding has little impact on cultivar development in wheat. Almost all the cultivars are derived from seedlings (Litz et $a l$. , 1994). The problem is intensified due to lack of resistance in available local and exotic cultivars.

In vitro studies against $B$. sorokiniana are barely sufficient and even precise information on determination of efficacy, sensitivity types of fungicides with minimum inhibitory concentration have not been characterized against B. sorokiniana (Iqbal, 2010). Research is needed to control this disease. Chemical control is the most preferable one in respect of India.

In view of the above facts, the present study was undertaken to evaluate the variable effects of some selected fungicides against some B. sorokiniana.

\section{Materials and Methods}

An experiment conducted in Plant Pathology Laboratory Narendra Deva University of Agriculture and Technology, Narendra Nagar, Kumarganj, Faizabad (U.P.) during 2015 Efficacy of 15 fungicides table 1 were evaluated at $0.05 \%, 0.5 \%, 0.1 \%$ and $2 \%$ for studying their inhibitory effect on the mycelia growth of Bipolaris sorokiniana by using food poison technique. (Grover and Moore 1962).

For preparation of different concentration of fungicides, fungicides were weighed with the help of electronic balance. The weighted fungicides were added to sterilized PDA. This PDA is poured in sterilized petridishes. PDA medium without fungicides were served as control. Four replications were maintained for each treatment in complete randomized design. 
Table.1 List of the fungicide, trade name, chemical name and supply source

\begin{tabular}{|c|c|c|c|c|}
\hline $\begin{array}{l}\text { S. } \\
\text { No. }\end{array}$ & $\begin{array}{l}\text { Common } \\
\text { name }\end{array}$ & Trade name & Chemical name & $\begin{array}{l}\text { Fungicide } \\
\text { group }\end{array}$ \\
\hline 1. & Achook & Achook & Azadirachtin-rich neem formulation & $\begin{array}{l}\text { Botanical } \\
\text { fungicide }\end{array}$ \\
\hline 2. & Carbendazim & Bavistin 50W.P. & Methyl 1Hbenzimidazol2ylcarbamate & $\begin{array}{l}\text { Benzimidazoles } \\
\text { fungicide }\end{array}$ \\
\hline 3. & Carboxin & Vitavax75 W.P & 5,6- dihydro- 2- methyl- 1,4- oxathiin- 3- carboxamide (56) & $\begin{array}{l}\text { Oxathiins } \\
\text { Fungicide }\end{array}$ \\
\hline 4. & $\begin{array}{l}\text { Copper } \\
\text { oxychloride }\end{array}$ & Blitox & Copper oxychloride & $\begin{array}{l}\text { Copper } \\
\text { fungicide }\end{array}$ \\
\hline 5. & Cyclohexamide & $\begin{array}{l}\text { Acti- dione } 2.26 \% \\
\text { W.P. }\end{array}$ & $\begin{array}{l}4[(2 \mathrm{R}) 2[(1 \mathrm{~S}, 3 \mathrm{~S}, 5 \mathrm{~S}) 3,5 \text { Dimethyl2oxocyclohexyl }] 2 \text { hydroxyethyl }] \\
\text { piperidine } 2,6 \text { dione }\end{array}$ & $\begin{array}{l}\text { Cyanoimidazole } \\
\text { (Antibiotic) }\end{array}$ \\
\hline 6. & Difenconazole & $\begin{array}{l}\text { InspireSuper, } \\
\text { Stadium }\end{array}$ & $\begin{array}{l}\text { cis,trans3chloro4[4methyl2(1H1,2,4triazol1ylmethyl)1,3dioxolan2yl] } \\
\text { phenyl4chlorophenylether }\end{array}$ & Triazoles \\
\hline 7. & Hexaconazole & Trigger & 2(2,4Dichlorophenyl)1(1H1,2,4triazol1yl) hexan2ol & Triazoles \\
\hline 8. & Iprodiane & $\begin{array}{l}\text { Chipco 26GT, } \\
\text { Raven Iprodione } \\
\text { Pro, } 18 \text { Plus }\end{array}$ & 3(3,5Dichlorophenyl) Nisopropyl2,4dioxoimidazolidine1 carboxamide & $\begin{array}{l}\text { Dicarboximide } \\
\text { Fungicide }\end{array}$ \\
\hline 9. & Kasugamycine & Kasumin & $\begin{array}{l}\text { 3-O-(2-Amino-4-((carboxyiminomethyl)amino)-2,3,4,6-tetrahydroxy- } \\
\alpha \text {-D-arabinohexopyran osyl-d-chiro-inositol hydrochloride }\end{array}$ & $\begin{array}{l}\text { Cyanoimidazole } \\
\text { (Antibiotic) }\end{array}$ \\
\hline 10. & Nativo & Nativo $75 \%$ & Tebuconazole $50 \%+$ Trifloxystrobin $25 \%$ & Triazoles \\
\hline 11. & Nimbicidine & Nimbicidine & Azadirachtin-rich neem formulation & $\begin{array}{l}\text { Botanical } \\
\text { fungicide }\end{array}$ \\
\hline 12. & Propiconazole & $\begin{array}{l}\text { Banner Maxx, } \\
\text { Honor Guard, } \\
\text { Procure, Quilt }\end{array}$ & 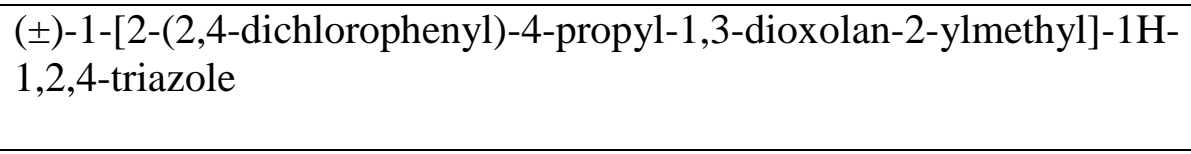 & Triazoles \\
\hline 13. & Proponeb & $\begin{array}{l}\text { Antracol } \\
70 \% \text { W.P. }\end{array}$ & Zinc proyllenebisdithocarbmate (polymeric) & $\begin{array}{l}\text { Dithiocarbamate } \\
\text { group }\end{array}$ \\
\hline 14. & Tebuconazole & Folicur, Toledo & $\begin{array}{l}\text { (RS)1(4Chlorophenyl) 4,4dimethyl3(1H,1,2,4triazol1 ylmethyl) } \\
\text { pentan3ol }\end{array}$ & Triazoles \\
\hline 15. & Tricyclazole & Blasticide & 5-methyl-1,2,4-triazolo[3,4-b][1,3]benzothiazole & Triazoles \\
\hline
\end{tabular}


Table.2 Effects of different fungicides at different concentrations on radial mycelial growth, mycelial growth inhibition of Bipolaris sorokiniana

\begin{tabular}{|c|c|c|c|c|}
\hline Treatments & Name of Fungicides & Concentration (percent) & Radial growth (mm) & Inhibition percentage \\
\hline $\mathrm{T}_{1}$ & Achook & 0.5 & 83.01 & $7.75(16.15)$ \\
\hline $\mathrm{T}_{2}$ & Achook & 0.2 & 89.56 & $0.78(3.17)$ \\
\hline $\mathrm{T}_{3}$ & Carbendazim & 0.1 & 67.56 & $24.94(29.95)$ \\
\hline $\mathrm{T}_{4}$ & Carbendazim & 0.05 & 75.12 & $16.52(23.97)$ \\
\hline $\mathrm{T}_{5}$ & Carboxin & 0.1 & 70.23 & $21.91(27.92)$ \\
\hline $\mathrm{T}_{6}$ & Carboxin & 0.05 & 50.98 & $12.78(20.85)$ \\
\hline $\mathrm{T}_{7}$ & Copper oxychloride & 0.1 & 65.33 & $27.02(31.28)$ \\
\hline $\mathrm{T}_{8}$ & Copper oxychloride & 0.05 & 71.60 & $20.43(26.86)$ \\
\hline $\mathrm{T}_{9}$ & Cyclohexamide & 0.1 & 71.24 & $20.78(27.08)$ \\
\hline $\mathrm{T}_{10}$ & Cyclohexamide & 0.05 & 76.81 & $14.92(22.69)$ \\
\hline $\mathrm{T}_{11}$ & Difenconazole & 0.1 & 59.66 & $33.69(35.47)$ \\
\hline $\mathrm{T}_{12}$ & Difenconazole & 0.05 & 69.17 & $32.13(28.73)$ \\
\hline $\mathrm{T}_{13}$ & Hexaconazole & 0.2 & 19.81 & $77.97(61.99)$ \\
\hline $\mathrm{T}_{14}$ & Hexaconazole & 0.1 & 26.65 & $70.37(57.00)$ \\
\hline $\mathrm{T}_{15}$ & Iprodiane & 0.2 & 44.72 & 50.345 .157 \\
\hline $\mathrm{T}_{16}$ & Iprodiane & 0.1 & 52.05 & $42.32(40.56)$ \\
\hline $\mathrm{T}_{17}$ & Kasugamycine & 0.3 & 32.24 & $64.17(53.21)$ \\
\hline $\mathrm{T}_{18}$ & Kasugamycine & 0.2 & 40.31 & $55.2(47.96)$ \\
\hline $\mathrm{T}_{19}$ & Nativo & 0.1 & 21.00 & $76.81(61.19)$ \\
\hline $\mathrm{T}_{20}$ & Nativo & 0.05 & 26.22 & $70.85(57.306)$ \\
\hline $\mathrm{T}_{21}$ & Nimbicidine & 0.5 & 80.57 & $10.46(18.86)$ \\
\hline $\mathrm{T}_{22}$ & Nimbicidine & 0.2 & 85.55 & $4.94(12.66)$ \\
\hline $\mathrm{T}_{23}$ & Propiconazole & 0.1 & 11.00 & $87.77(69.51)$ \\
\hline $\mathrm{T}_{24}$ & Propiconazole & 0.05 & 16.57 & $81.57(64.56)$ \\
\hline $\mathrm{T}_{25}$ & Proponeb & 0.1 & 55.25 & $38.69(38.46)$ \\
\hline $\mathrm{T}_{26}$ & Proponeb & 0.05 & 60.78 & $32.47(34.71)$ \\
\hline $\mathrm{T}_{27}$ & Tebuconazole & 0.1 & 35.32 & $60.74(51.18)$ \\
\hline $\mathrm{T}_{28}$ & Tebuconazole & 0.05 & 41.90 & $54.6(47.66)$ \\
\hline $\mathrm{T}_{29}$ & Tricyclazole & 0.1 & 39.82 & $55.76(48.29)$ \\
\hline $\mathrm{T}_{30}$ & Tricyclazole & 0.05 & 50.72 & $43.63(41.32)$ \\
\hline $\mathrm{T}_{31}$ & Control & & 90.00 & $0(0.00)$ \\
\hline \multicolumn{3}{|l|}{ SEm \pm} & 1.01 & 0.82 \\
\hline \multicolumn{3}{|l|}{$\mathrm{CD}(\mathrm{P}=0.05)$} & 2.84 & 2.32 \\
\hline \multicolumn{3}{|l|}{ CV $(\%)$} & 4.51 & 3.71 \\
\hline
\end{tabular}

() Figures in parentheses are transformed angular value 
After solidification, $5 \mathrm{~mm}$ discs of Bipolaris sorokiniana were cut from the margin of actively growing colony and inoculated on to the center of the Petri dish containing the poisoned PDA medium. Petridishes were incubated at $27 \pm 2{ }^{0} \mathrm{C}$ temperature. Colony diameter was measured after seven days.

Measurement of radial mycelia growth and growth inhibition of $\boldsymbol{B}$. sorokiniana

$$
\mathrm{I}=\frac{\mathrm{C}-\mathrm{T}}{\mathrm{C}} \times 100
$$

Where,

$\mathrm{I}=$ Inhibition of mycelium.

$\mathrm{C}=$ Colony diameter $(\mathrm{mm})$ in control.

$\mathrm{T}=$ Colony diameter $(\mathrm{mm})$ in treatment.

\section{Experimental design and data analysis}

Both experiments were laid out under completely randomized design (CRD). Data were transformed by using Square Root Method (Zaman, 1982) for exactly analyzing the data avoiding statistical complication.

\section{Results and Discussion}

Fifteen fungi-toxicants used in the present study were evaluated in vitro against Bipolaris sorokiniana spot blotch of Barley by Food Poison Technique at the recommended dose along with the other dose of 15 fungi- toxicants.Fifteen fungi toxicants were used in the present study were evaluated in vitro against Bipolaris sorokiniana causes spot blotch of Barley by Food Poison Technique using fungi toxicant one recommended dose and one other dose. In present study the data was recorded, the maximum mycelial growth inhibition was recorded in inoculation after 7 days table 2 Propiconazole $(0.1 \%) \quad 87.77 \%$, and Propiconazole $(0.05 \%) \quad 81.57 \%$ and radial mycelial growth $11.00 \mathrm{~mm}$ and $16.57 \mathrm{~mm}$ followed by Hexaconazole $(0.2 \%)$ and Hexaconazole $(0.1 \%) 77.98 \%$ and $70.37 \%$ mycelial growth inhibition and radial mycelial growth $19.81 \mathrm{~mm}$ and $26.65 \mathrm{~mm}$. The lowest mycelial growth inhibition was recorded $\mathrm{T}_{1}$ Achook $0.5 \%$ and $\mathrm{T}_{2}$ Achook $0.2 \% 7.75 \%$ and $0.78 \%$ and radial mycelia growth $83.01 \mathrm{~mm}$ and $89.56 \mathrm{~mm}$ respectively. As per result agreed with Hasan et al., (2012), and Samia et al., (2015) Mancozeb, Carbendazim, Propiconazole and Copper Oxychloride was used in the study. No mycelial growth was found even at the lowest concentration of Propiconazole after 7 days of inoculation in all isolates of Bipolaris sorokiniana. Chattopadhyay et al., (2013) tested the tricyclazole, it reduces the spore size, average number of septation and extent of sporulation in fungi in vitro condition. Singh and Gupta (2000) studied the bioassay of fungicides against Dreschlera sativus causing leaf blight of wheat. Tilt was most effective fungicide in inhibiting the mycelial growth. Chandrashekara (2013) and Prem et al., (2013) Fungicide Zineb, Thiram, TPTA and Ziram were completely inhibited the radial growth of Bipolaris sorokiniana, in vitro The results revealed that inhibition percentages were increase with the increased in concentration of all fungicides used in this study.

\section{References}

Anonymous, 2016. Wheat and Barley Improvement Project progress report All India Coordinated (Vol. VI) ICARIndian Institute of Wheat and Barley Research.

Dhingra, O.D., and J.B. Sinclair. 1985. Basic Plant Pathology Methods. Department of Plant Pathology. University of Illionis, USA. Plant Dis., 132-163.

Grover, R.K., and Moore, J.D. 1962. Toximetric studies of fungicides against 
brown rot organism. Sclerotina fruticola. Phytopathology. 52: 876-880.

Hasan, M.M., Ahmed F, Islam MR, Murad KFI, 2012. In vitro effect of botanical extracts and fungicides against Bipolaris sorokiniana, causal agent of leaf blotch of barley. J. Agrofor. Environ, 6: 83-87.

Iqbal, Z., Pervez MA, Ahmad S, Iftikhar Y, Yasin M, Nawaz A, Ghazanfara MU, Dasti IA, Saleem A, 2010. Determination of minimum inhibitory concentrations of fungicides against fungus Fusarium mangiferae. Pak. $J$. Bot., 42: 3525-3532.

Litz, R.F., Ploetz RC, Zentmyer GA, Nishijima WT, Rohrbach KG, Ohr HD, 1994. Mango. In: Compendium of tropical fruit diseases. (Eds.). The APS Press, St. Paul, Minn., U.S.A.

McGrath, M.T., 2004. What are Fungicides? The Plant Health Instructor. DOI: 10.1094/PHI-I-2004-0825-01.

Mian, I.H., 1995. Methods in Plant Pathology, IPSA-JICA project publication. Institute of Postgraduate Studies in Agriculture, Gazipur, Bangladesh. No.24 Microspora spores. J. Theoret. Biol., 142: 223-235.

Pandey, S., Kumar, S., Kumar, U., Chand, R. and Joshi, A. 2005. Sources of inoculum and reappearance of spot blotch of wheat in rice-wheat cropping. European Journal of Plant Pathology, 111:47-55.

Prem, N., Biswas, S.K., and Kumar, R. 2013. Effect of Media, $\mathrm{pH}$, Temperature, Host range and Fungicides on Bipolaris sorokiniana. Journal of Life Sciences, 10: 433- 440.

Rahman, M.M., Ali MS, Nahar A, Karim MM, Begum K, 2013. Efficacy of fungicides in controlling leaf blight of wheat. Int. J. Expt. Agric., 3: 1-3.

Shamim Iftikhar, Shahzad Asad, Atiq-Ur Rehman Rattu, Mohammad-Fayyaz, Anjum Munir 2009. Selection of Barley germplasm resistant to Spot blotch. Pakistan Jo, of Botany, 41 (1): 309-314.

Sharma, R.C., and Duveiller, E. 2006. Spot blotch continues to cause substantial grain yield reductions under resourcelimited farming conditions. Journal of Phytopathology, 154: 482-488.

Sultana, A., Rashid AQMB, 2012. Effect of seed category as affected by Bipolaris sorokiniana on the germination of wheat Seeds. J. Environ. Sci. Nat. Resour., 5: 113-116.

\section{How to cite this article:}

Kavita, S.K. Pande, Jay Kumar Yadav and Dalbeer. 2017. In vitro Evaluation of Fungicides against Bipolaris sorokiniana Causing Spot Blotch of Barley (Hordeum vulgare L.). Int.J.Curr.Microbiol.App.Sci. 6(10): 4734-4739. doi: https://doi.org/10.20546/ijcmas.2017.610.439 